\title{
Wages and prices in early Catalan industrialisation
}

\author{
Julio Martínez-Galarraga (Universitat de València) \\ Marc Prat (Universitat de Barcelona)
}

\section{Julio Martínez-Galarraga}

Departament d'Anàlisi Econòmica, Universitat de València,

Av. dels Tarongers s/n, 46022 València, Spain

e-mail: Julio.Martinez-Galarraga@uv.es

\section{Marc Prat}

Departament d'Història i Institucions Econòmiques, Universitat de Barcelona

Av. Diagonal 690, 08034 Barcelona, Spain

e-mail: marc.prat@ub.edu

\begin{abstract}
Catalonia was the only Mediterranean region among the early followers of the British Industrial Revolution. The roots of this process can be traced back to the seventeenth and eighteenth centuries when the Catalan economy became integrated in international trade, and a successful printed calico manufacture concentrated in the city of Barcelona. Although the factory system was largely adopted by the cotton industry in the 1840s, the diffusion of the spinning jenny in Catalonia had occurred earlier in the 1790s. In line with Allen, we explore whether relative factor prices played a role in the widespread adoption of the spinning jenny in Catalonia. First, we supply series of real wages in Barcelona for 15001808. Second, we compare the prices of labour and capital and analyse the potential profitability of the adoption of the spinning jenny. We find that although Catalonia was not a high wage economy in the way that Britain was in the second half of the eighteenth century, evidence from the cotton spinning sector confirms the relevance of relative factor prices in the adoption of new technology. Within the booming sector of cotton after the 1780s, high wages created strong incentives for adopting the labour-saving spinning jenny.
\end{abstract}


"The Iberian Peninsula [...] had one major industrial region which could stand comparison with the classical regions of Inner Europe: Catalonia. The eighteenth century saw a rapid population increase there accompanied by an agricultural revolution which allowed the Catalans to fill up their empty lands, irrigate hitherto infertile areas, and expand the cultivation of old and new cash crops. Above all, however, the cotton industry developed in what was as early as 1770 called 'a little England in the heart of Spain'”.

Sidney Pollard, Peaceful Conquest, 1981, p. 106.

Catalonia was the only Mediterranean region among the early followers of the British Industrial Revolution in the nineteenth century. The early stages of this industrialisation process were strongly characterised by a specialisation in cotton so that between 1835 and 1861 almost all the cotton spinning and half of the weaving industries in Catalonia adopted the factory system. ${ }^{1}$ This leading role was complemented by other branches of textiles and, eventually, by other industrial sectors. In Jordi Nadal's words during the nineteenth century Catalonia became 'the factory of Spain'. As Sidney Pollard pointed out, the roots of this economic modernisation can be traced back to, at least, the eighteenth century. Catalonia had enjoyed a process of market development since the end of the seventeenth century, which had led to an intensification of its agrarian and proto-industrial sectors and rapid population growth during the eighteenth century. ${ }^{2}$ This had been the result of the successful integration

\footnotetext{
${ }^{1}$ Nadal, Fracaso.

2 Vilar, Catalogne; Torras, 'L'economia'.
} 
of the Catalan economy into the international trade of the Early Modern period. ${ }^{3}$ Furthermore, since 1736 printed calico manufacturers had begun to establish themselves in Barcelona. In the last two decades of the century the manufacture achieved a significant size and by 1786 Barcelona was the leading printing textile city in Europe. ${ }^{4}$ Initially, most of the yarn used as raw material in production was imported from Malta, but during these decades cotton spinning began to expand rapidly and conditions were ripe for the adoption of the spinning jenny. The new machine arrived in Catalonia in the 1780 s and was widely adopted in the 1790 s. It is in this economic context that Catalonia has come to be known as 'a little England in the heart of Spain'.

The British Industrial Revolution remains one of the leading topics of discussion in economic history today. Why did the Industrial Revolution occur in Britain? Why did it not happen in the Low Countries, France or China, for example? Why did it occur at the end of the eighteenth century? These questions have been approached in a variety of ways giving rise to a rich intellectual debate. Marxists stress the importance of the rise of capitalism, with its free markets and landless proletariat. ${ }^{5}$ On the other hand, institutionalists attribute this economic transformation to the English Glorious Revolution of 1688, which limited the King's despotic behaviour and secured property rights. ${ }^{6}$ Other attempts at explanation stress alternatively the Scientific Revolution, the Protestant ethic, ${ }^{7}$ the capacity of the British entrepreneurs and the role of technology, ${ }^{8}$ the Industrial Enlightenment, ${ }^{9}$ or even the spread of middle class values from the elite to other social groups for "biological" reasons. ${ }^{10}$ An alternative explanation,

\footnotetext{
${ }^{3}$ Valls, Catalunya.

${ }^{4}$ Sánchez, 'La era'; Thomson, 'Technological'.

${ }^{5}$ Marx, Das Kapital.

${ }^{6}$ North and Weingast, 'Constitutions'.

${ }^{7}$ Weber, Protestant.

${ }^{8}$ Landes, Unbound.

${ }^{9}$ Mokyr, Enlightened.

${ }^{10}$ Clark, Farewell.
} 
based on economic factors, has recently been proposed by Robert Allen. ${ }^{11}$ In his view, in line with Habakkuk, ${ }^{12}$ the key to the Industrial Revolution lay in the demand for new technologies, which in turn depended on relative factor prices. First, Britain had become a high wage economy during the modern period. Additionally, the stability of its capital markets and the availability of cheap energy favoured the emergence of a price structure in Britain that created a strong incentive to research and develop new technologies to substitute cheap inputs (energy and capital) for the relatively more expensive factor input (labour). Allen exemplifies the importance of relative prices by examining the adoption of the first technological innovation in the cotton sector: ${ }^{13}$ the spinning jenny invented by Hargreaves in 1764 . He conducts a micro-economic analysis concluding that the ratio between the wages of spinners in English cottages and the price of purchasing a jenny made inventions profitable in England, but not in France or India. The story of the spinning jenny thus confirms his endogenous explanation of the British Industrial Revolution, where the demand for new technologies was a key variable.

In the Catalan case, it is a well-documented fact that the spinning jenny was rapidly adopted in Barcelona, medium-sized towns and rural areas from the last decade of the eighteenth century onwards. But how does the Catalan experience fit within this 'demand for technology'-based explanation? Several authors have stressed that, in the second third of the nineteenth century, supply-side arguments might explain the delay in the adoption of new technologies (primarily, the steam engine) in Catalonia. The repeal of the British ban on machinery exports in 1842 would have favoured a process of technology transfer in the cotton industries that, together with a more stable economic and political atmosphere, would have gone someway to overcoming the technological backwardness experienced in the spread of

\footnotetext{
${ }^{11}$ Allen, British Industrial Revolution.

12 Habbakuk, American.

${ }^{13}$ Allen, 'Industrial Revolution '.
} 
steam-based industrialisation. ${ }^{14}$ In addition to this, the historiography has also highlighted that one of the main handicaps for Catalan industrialisation in the nineteenth century was the lack of cheap coal. ${ }^{15}$ Nonetheless, the adoption in Catalonia of the simplest textile machine, the spinning jenny, at the end of the eighteenth century was not hindered by supply-side factors because the transmission of this technology was much easier. And energy restrictions did not play a decisive role here either, as the spinning jenny was powered by hand, so the only relevant factors were capital and labour.

The first contribution of this paper is the analysis it undertakes of the evolution of wages and prices in Barcelona, the capital city of Catalonia, during the modern period. Here, we draw on the information gathered by Gaspar Feliu whose remarkable work provides a large amount of wage and price data for different occupations and goods, respectively, between 1500 and $1808 .{ }^{16}$ This information allows us, on the one hand, to present long-term series of living standards in Barcelona and, on the other, to add the Catalan case to the global picture within the 'Great Divergence' debate. ${ }^{17}$ Based on the nominal wages for construction labourers and a typical subsistence basket, real wages are computed by calculating the subsistence ratio. ${ }^{18}$ Our results show, in a global comparative perspective, that the evolution of living standards in Barcelona throughout the period fits well with the so-called continental European pattern, somewhat below that of the high wage economies of Atlantic Europe (England and the Low Countries).

\footnotetext{
${ }^{14}$ Thomson, Distinctive.

15 Nadal, Fracaso.

${ }^{16}$ Feliu, Precios y salarios, vol. I and II.

17 Van Zanden, 'Wages'; Pomeranz, Great divergence; Allen, 'Great divergence'; Broadberry and Gupta, 'Early modern'; Pamuk, 'Urban'; Bassino and Ma, 'Japanese'; Allen, Bassino, Ma, Moll-Murata, Van Zanden, 'Wages'; Allen, Murphy, Schneider, 'Colonial origins'.

${ }^{18}$ Allen, Murphy, Schneider, 'Colonial origins'.
} 
In the light of these results, can the early adoption and the successful diffusion of the spinning jenny in the last decade of the eighteenth century in Catalonia be explained in terms of the 'demand for technology' argument? What were the relative prices of the two relevant production factors (labour and capital) used in the new machines? Following Allen, we measure relative prices as the ratio between the price of labour and the price of capital. ${ }^{19}$ We then look at this ratio at an aggregate level for the whole economy and directly for the cotton spinning sector. The micro-level analysis examines whether differences in factor prices made it profitable for domestic producers to purchase a spinning jenny based on the rate of return of such an investment. ${ }^{20}$ Our results show that, under alternative scenarios, the potential profitability of the spinning jenny in Catalonia generated strong incentives for adopting new, labour-saving machines in cotton spinning, a booming sector in the general context of the Catalan economy. The spinning jenny began to be adopted across Catalonia in the 1790 s, in a process that also involved a technological improvement to the machines. ${ }^{21}$

The reminder of the paper is organised as follows. The next section summarises the main characteristics of the Catalan economy in the eighteenth century, paying special attention to the cotton textile sector and the early adoption and diffusion of spinning machines across Catalonia. Section 3 is devoted to the construction of real wage series for Barcelona between 1500 and 1808 . In section 4 relative factor prices are analysed and in section 5 we undertake a micro-level analysis of profitability for the first spinning jennies installed in Catalonia. Interestingly, the exercises conducted allow us to examine our results in comparative perspective with Britain and France. Once our findings are discussed, the final section concludes.

\footnotetext{
${ }^{19}$ Allen, British Industrial Revolution; idem, 'Industrial Revolution'.

${ }^{20}$ Idem, 'Industrial Revolution'.

${ }^{21}$ Sánchez, 'Berguedanes'.
} 
Economic historians have stressed that Catalonia enjoyed Smithian economic growth from as early as the seventeenth century. According to Jaume Torras, a combination of two factors accounts for the changes in the specialisation of the Catalan economy. ${ }^{22}$ First, in the context of French-Dutch rivalry and wars, certain Mediterranean areas were given the opportunity to attain a fuller economic integration with the European markets by exporting wines and liqueurs. Second, the structure of Catalan land and property rights enabled the region's producers to react positively to this opportunity. As a result, the planting of grapevines expanded substantially, and many areas in Catalonia, especially those located near the coast, became specialised in vineyards. As Francesc Valls explains, the Catalan economy achieved a significant degree of integration with Atlantic Europe during this period. ${ }^{23}$ At the same time, the rising population in those areas devoted to vineyards increased the number of potential consumers for other goods such as grain and manufactures. Thus, while some areas advanced in their specialisation of grapevines, other areas began to specialise in the production of cereals and manufactures. ${ }^{24}$ As this process evolved, an increasing number of households began to produce in order to sell in the market and, eventually, Catalonia developed into capitalism..$^{25}$

Specialisation and greater market involvement favoured the advance of manufacturing in Catalonia, especially as regards the production of woollen fabrics. Several areas of Central Catalonia and the Pyrenean foothills flourished thanks to this activity, following a protoindustrial pattern characterised by the intensive use of the rural labour force for producing new draperies. ${ }^{26}$ This proto-industry in the wool sector was eventually to play a key role in the

\footnotetext{
22 Torras, 'L'economia'.

${ }^{23}$ Valls, Catalunya.

${ }^{24}$ Torras, 'Especialización'.

${ }^{25}$ Vilar, Catalogne.

26 Torras, 'Estructura'.
} 
development of cotton manufacturing. Extensive putting-out networks, skilled labour, organisational capabilities and the availability of capital all contributed to the advent and diffusion of cotton manufacturing in the last quarter of the eighteenth century. ${ }^{27}$ Indeed, in this respect Catalonia can be considered a successful case in the transition from proto-industry to industrialisation. This process was further strengthened thanks to access to the Spanish market, following the elimination of domestic barriers, and to the progressively improved access to the colonial markets in America during the eighteenth century. Catalonia played a pivotal role between Atlantic Europe and Spanish America, exporting liqueurs and importing textiles from the former, while re-exporting textiles to the latter. ${ }^{28}$ Thus, Catalonia was to experience a process of agrarian intensification and mercantile and manufacturing growth that led to a constant rise in population throughout the eighteenth century, as Pierre Vilar narrates in his classic study. ${ }^{29}$ The population of Catalonia almost doubled between 1718 and 1787, the year in which it reached almost 900,000 inhabitants. Between these same two dates, the city of Barcelona more than tripled its population, rising from 36,781 to 125,745 inhabitants. ${ }^{30}$

It is against this background that the calico-printing sector began to emerge in Barcelona. ${ }^{31}$ Manufacturing was initiated, as in other cases in Europe, when a ban was placed on the importation of Asian textiles. The prohibitionist measures imposed by the Spanish Monarchy during the second and third decades of the eighteenth century promoted import substitution and the development of the domestic manufacture of printed calicoes after 1736 in the city of Barcelona. This was a new emerging sector, free from any guild regulations, that for technical reasons concentrated a large number of workers in a single space and in which

\footnotetext{
${ }^{27}$ Okuno, 'Entre la llana'.

${ }^{28}$ Valls, Catalunya.

${ }^{29}$ Vilar, Catalogne.

${ }^{30}$ Badia, M., Tello, E., 'An inner-frontier model to explain vine-growing specialization in the province of Barcelona in the mid-nineteenth century', mimeo (2013).

31 On the rise of printed calico manufactures in eighteenth century Barcelona, see Thomson, 'Explaining'; Sánchez, 'Orígens'; Raveux and Sánchez, 'Adaptación'; and the references therein.
} 
high capital investments were required. ${ }^{32}$ During the second half of the eighteenth century, the sector underwent a rapid expansion.

In the printed calico establishments of Barcelona manufactures were woven and printed, but no spinning was undertaken. Indeed, for a long period, cotton spinning was a marginal activity in Catalonia, with most of the yarn being imported from Malta. It was again a protectionist measure implemented by the government - the introduction of a 20 per cent tariff on foreign raw cotton and yarn - that fostered domestic spinning. The main objective of the government was to promote raw cotton imports from its Spanish American colonies. In 1772, the manufacturers of printed calico in Barcelona reacted by founding the Royal Company of American Cotton Yarn (Real Compañía de Hilados de Algodón de América). ${ }^{33}$ The Royal Company was a chartered company that embraced all printed calico manufacturers in Barcelona. Initially, it aimed to promote national spinning by exploiting the existing putting-out networks of wool spinners. However, this venture was to be short-lived. In 1783, the Royal Company was refounded, at a time when, following the conclusion of the first war against Britain, the American raw cotton supply could once more be guaranteed and the production of printed calicoes and the printing of imported linen were booming thanks to exports to Spain's colonial markets. ${ }^{34}$ In fact, in 1786 Barcelona became Europe's leading textile printing city: "The city contained some 113 calico-printing manufactories by 1786, by far the densest concentration in the industry in Europe. By way of comparison, the number of calico printing concerns in Britain and France in 1785 was 111 and 114 respectively, and the number in Switzerland [...] was 59 in the 1790s".$^{35}$ In 1796, the printed calico factories of Barcelona were employing 12,979 workers. ${ }^{36}$ Although a major share of output was foreign linen and cotton

\footnotetext{
32 Sánchez, 'La era'.

33 Raveux and Sánchez, 'Adaptación'.

${ }^{34}$ Ibid.

35 Thomson, 'Technological', p. 255.

${ }^{36}$ Sánchez, 'Activitats', p. 248.
} 
fabrics printed in Barcelona for export to the Spanish American colonies, cotton weaving and spinning also began to boom during these years. By 1792 the cotton weaving sector in Catalonia was equivalent in size to 16 per cent of the British sector. ${ }^{37}$

The Royal Company established two systems for yarn provision. On the one hand, it depended on the longstanding tradition of wool spinning in Central Catalonia, exploiting the putting-out networks controlled by local weavers and finishers. On the other, the company set up its own workshops in various locations in Southern and Western Catalonia without any manufacturing tradition or local businessmen, but with cheaper unskilled labour. However, this second system proved unsuccessful and the Company abandoned it in 1787 . At the same time, many independent businessmen that controlled the putting-out networks for wool spinning had now moved into cotton spinning and so competed directly with the Royal Company. In short, the Royal Company failed to achieve a cotton spinning monopoly and was unsuccessful in its attempts to colonise areas with no manufacturing tradition. However, it made a decisive contribution to the diffusion of cotton spinning in Catalonia. The Royal Company together with independent businessmen promoted a shift from putting-out networks dedicated to spinning wool to networks spinning cotton and the 'nationalisation' of this activity was achieved in just a few years. The Catalan case is exceptional in this sense: cotton spinning was introduced late, but once in motion the jenny was quickly and widely adopted. ${ }^{38}$

The spinning jenny reached Catalonia in 1784 via France. The first attempt at adoption was made in a mill, ${ }^{39}$ but subsequently the jennies were mostly used in small domestic workshops. In 1787, the Royal Company established a mill in Barcelona where 14 spinning

\footnotetext{
${ }^{37}$ Vilar, 'Catalunya industrial', p. 9.

${ }^{38}$ Raveux and Sánchez, 'Adaptación'; Garcia Balañà, Fabricació; Okuno, 'Entre la llana'.

${ }^{39}$ The term mill refers to centralised manufactures predating the factory system.
} 
jennies operated. ${ }^{40}$ However, as Garcia Balañà has pointed out, it was quickly realised that this model was not the best way to maximise profits because the women that spun came from household economies and as workers they had few incentives to stay in the mill during long working days or to remain in its employment for a long period of time ${ }^{41}$ Thus, the Royal Company opted to close down its spinning mill in 1792, while a second attempt, in this case led by Erasme de Gònima, ended in a similar way in 1802 . The most profitable way to exploit the new technology was in the domestic workshops in Barcelona or in the cottages in the traditional textile areas of Central Catalonia and the Pyrenean foothills. By as early as 1791 , there were at least 108 spinning jennies in Catalonia and throughout that next decade they were widely adopted. ${ }^{42}$ Moreover, after 1792 , Haley's improved version of the jenny, with 78 80 spindles, was built in Central Catalonia, with a total of 250 machines being reported operational in 1796. This was the origin of what would later become known as the 'berguedanes'. Thus, by the beginning of the nineteenth century, Catalonia boasted spinning jennies (each with between 36 to 110 spindles) with a total of 90,000 spindles. ${ }^{43}$

The adoption of new technologies in the cotton sector did not end with the spinning jenny. The water frame arrived in Catalonia in 1793, although its diffusion would have to wait until the first years of the nineteenth century. These machines were ten times more expensive than the biggest jennies and required much more energy to operate. Thus, water frames, which were located in mills near the region's rivers, were more appropriate for use in a factory system. On the eve of the Peninsular War (1808), a total of 12,000 water frame spindles had

\footnotetext{
40 Thomson, 'Transferring'. For an overview of technological innovations in the Catalan cotton manufacture and cotton industry, see Ferrer, 'Bergadanas'; Sánchez, 'Berguedanes'; Thomson, 'Transferencia'.

${ }^{41}$ Garcia Balañà, Fabricació.

42 Sánchez, 'Berguedanes'. See also Solà, 'Indústria tèxtil'.

43 Sánchez, 'Berguedanes', pp. 164-70.
} 
been installed in Catalonia. ${ }^{44}$ In turn, the mule jenny had just been introduced and accounted for a further 2,000 spindles. ${ }^{45}$ However, while Catalonia was an early British follower, rapidly adopting the spinning jenny, it was not so successful in its introduction of the water frame or the mule jenny. The lack of coal and the scarcity of waterpower proved a major constraint for the large-scale adoption of these innovations, which did not really take off until the 1840s, when the diffusion adhered much more closely to the Continental pattern. The first cotton factory to employ steam power - 'Bonaplata, Rull, Vilaregut i companyia' - was opened in Barcelona in 1833. By then, in 1830, the number of cotton spindles operating in Catalonia had reached a total of $1,162,237$ (of which $89 \%$ were jennies). This figure was equivalent to 10 per cent of the British cotton spindles and 28 per cent of those installed in Continental Europe. ${ }^{46}$

Overall, between 1783 and 1796, thanks to the new peace signed with Britain and the rise in colonial trade, printed calicoes and linen manufactures enjoyed their belle époque. ${ }^{47} \mathrm{At}$ the same time, cotton spinning expanded in Catalonia and the spinning jenny was widely adopted. In this context, Vilar argues that high wages in Barcelona attracted workers from the rest of Catalonia creating a labour shortage in the countryside. ${ }^{48}$ The consequent rise in rural wages, and the lower wage gap between the city and the countryside, is seen by Mora-Sitjà as an indication of growing integration in rural-urban regional labour markets during this period..$^{49}$ In addition, she stresses that, in spite of the large population growth recorded during the eighteenth century, wages did not fall, indicating that Catalonia was escaping the Malthusian trap..$^{50}$ However, Marfany, ${ }^{51}$ analysing one of Catalonia's most dynamic industrial

\footnotetext{
44 Ibid., pp. 170-2; Raveux and Sánchez, 'Adaptación', pp. 75-7; Thomson, 'Transferencia', pp. 24-27; Solà, 'Filar'.

${ }^{45}$ Sánchez, 'Berguedanes', pp. 172-5.

${ }^{46}$ Farnie, 'Role of merchants', p. 23.

${ }^{47}$ Raveux and Sánchez, 'Adaptación'.

${ }^{48}$ Vilar, 'Catalunya industrial'.

49 Mora-Sitjà, 'Labour market'.

50 Mora-Sitjà, 'Labour and wages'.

${ }^{51}$ Marfany, 'Is it still helpful'; idem, Land; idem, Marfany, J., 'Terra, proto-indústria i població a Catalunya: una altra transició al capitalisme?’, mimeo (2012).
} 
towns of that century - Igualada -, argues that the industriousness and the market oriented activity of many Catalans was not to satisfy a desire for higher consumption levels, as was the case in north-western Europe, ${ }^{52}$ but rather to survive and to nurture a growing population on scarce land. Thus, the labour intensification process in the region's vineyards and manufacturing sector was not accompanied by rising income and consumption levels, but only by population growth. Based on this situation, the historiography is not unanimous in describing the wage levels achieved in Catalonia at the end of the eighteenth century. The section that follows seeks to offer quantitative evidence in this regard from a European comparative perspective.

\section{III}

The first step in our research strategy is to compute real wages for Barcelona in the long run from the sixteenth to the beginning of the nineteenth centuries. Our database is built from the wage and price information collected by Feliu. ${ }^{53}$ In an exhaustive study, this author reports an enormous amount of information regarding both the wages for a range of occupations and the prices of consumer goods in the city of Barcelona between 1500 and 1808. Our methodology for constructing real wages for Barcelona follows previous studies in the field so as to be able to undertake a comparison with existing evidence on real wages in a growing sample of cities around the world. ${ }^{54}$

\footnotetext{
${ }^{52}$ De Vries, Industrious.

${ }^{53}$ Feliu, Precios y salarios, vol. I and II.

${ }^{54}$ Allen, 'Great divergence'; Allen, Bassino, Ma, Moll-Murata, Van Zanden, 'Wages'; Allen, Murphy, Schneider, 'Colonial origins'. Detailed information of the wages and prices series used to calculate real wages and the methodological issues involved in such calculations can be consulted in the working paper version (XXXX).
} 
First, we compute the daily nominal wages of labourers working in the construction sector. ${ }^{55}$ The unit of account in the primary sources is sous catalans which have to be converted into grams of silver. The results presented in Figure 1 allow us to describe the evolution of nominal wages for construction labourers in Barcelona between 1500 and 1808 . Interestingly, the significant progress that has been made in the production of comparable long-term series of wages in the context of the 'Great Divergence' debate allows us to place the Catalan experience within the increasingly complete international picture. For the sake of simplicity, we confine our comparison to just a few leading European cities (London, Amsterdam, Florence/Milan and Vienna). First of all, Barcelona stands out at the beginning of the sixteenth century for having higher nominal wages. Between 1550 and 1650, a period of wage dispersion across Europe's cities, Barcelona retained this position, although wages in north-west Europe were already higher. In the next century, while wages continued to increase in London and remained stable in the Low Countries, in Barcelona the decrease in wages followed the tendency observed for other cities in continental Europe. By 1750, nominal wages in Barcelona had fallen to the levels recorded at the beginning of the sixteenth century; however, wages were still higher in Barcelona than those paid in Northern Italy and Vienna. From that moment on an exceptional increase was recorded in nominal wages, a rise that was not observed in the wages of its continental counterparts. These findings are supplemented by Table 1.

Figure 1

Table 1

Nominal wages hide, nonetheless, differences in the cost of living and in inflation across locations. In order to obtain a clear image of the incomes of workers and, as such, of

\footnotetext{
${ }^{55}$ Feliu, Precios y salarios, vol. II.
} 
their comparative standards of living, the usual problems raised with nominal variables have to be overcome. Real wages are usually obtained by comparing nominal wages to a consumer price index. Here, as is common in the related literature, this consumer price index is estimated by calculating a consumption basket that represents the minimum for subsistence, including a number of goods that are considered to be representative of the consumption of an adult male per year in the period under study. ${ }^{56}$ The basket includes food providing around 1940 calories per day, which is very close to the minimum in-take of calories for survival; in addition, some non-food items, including cloth, soap and fuel are also incorporated (Table 2$)^{57}$.

Table 2

There are, of course, differences in the consumption patterns across countries. As in pre-industrial societies cereals represented a large share of budget expenditure, the basket is geographically adapted to consider the different grains available depending on the area studied and based on the regional diet (for instance, oats in Northern Europe, polenta in Northern Italy, and wheat in Southern Europe). In our calculations for Barcelona, an equivalent quantity of the cheapest and most common grain, wheat, has been taken. Another example in this sense would be the inclusion of olive oil in the basket for Southern European countries instead of butter; or the use of canvas and linen to represent textiles. Likewise, a fuel consumption of $2 \mathrm{~m}$ British Thermal Units (BTUs) per year is used for Barcelona, in line with other Mediterranean countries where more temperate climates reduce the amount of heating fuel required. The time series of prices between 1500 and 1808 are likewise obtained from Feliu. ${ }^{58}$ The results in Table 3 show that the cost of acquiring the goods in the subsistence

\footnotetext{
${ }^{56}$ Allen, British Industrial Revolution; Allen, Bassino, Ma, Moll-Murata, Van Zanden, 'Wages'; Allen, Murphy, Schneider, 'Colonial origins'.

${ }^{57}$ See Humphries, 'Lure of aggregates' for a critical view on Allen's methodology, and his response in Allen, 'High wage economy'.

${ }^{58}$ Feliu, Precios y salarios, vol. I and II.
} 
basket in Barcelona (expressed in grams of silver) was higher than in the rest of Europe. This reflects the outcome of the Price Revolution in Spain and the inflationary effect of the arrival of silver from the Americas, which resulted in a persistent and general increase in prices. ${ }^{59}$ The inclusion of Valencia/Madrid in the last column of the table illustrates that a similar evolution (and one that was even more extreme) in the cost of living took place in other cities in Spain.

Table 3

Finally, real wages can be conventionally obtained by calculating the ratio between nominal wages and a standard consumer price index. As mentioned above, the strategy adopted here is in line with previous research in the field. ${ }^{60}$ The aim is to examine the purchasing power of the wages earned by a labourer on a yearly basis in relation to the annual cost of subsistence of a representative family. The construction of this subsistence ratio requires a number of assumptions be made. First, a labourer's daily wages have to be converted into annual earnings, assuming a total of 250 days of work per year. Second, the cost of the subsistence basket, which is already expressed in annual terms, is increased by a constant mark-up of $5 \%$ to include housing costs, that is, the estimated amount spent on rent. Finally, a representative family consisting of two adults and two children is assumed ${ }^{61}$. The cost of keeping this family at subsistence levels is considered to be equivalent to an annual payment of three baskets such as the one described in Table $2 .{ }^{62}$

The interpretation of this subsistence ratio has certain advantages over more conventional wage indexes. First, it provides a useful answer to the question: can a man working full time for a year support a family at the minimum subsistence level? A ratio below

\footnotetext{
${ }^{59}$ Hamilton, American; idem, War and Prices; Drelichman, 'Curse of Moctezuma' and the works cited therein.

${ }^{60}$ Allen, Murphy, Schneider, 'Colonial origins'.

${ }^{61}$ Schneider (Schneider, 'Real wages') has suggested an adjustment of Allen's real wages (Allen, 'Great divergence') to changing demography and variations in household composition in early modern England. ${ }^{62}$ Allen, 'Great divergence'.
} 
one indicates that families face economic hardships, as the yearly income is not sufficient to keep the family at the subsistence level. If the ratio is above one, then families enjoy a surplus and can expand their consumption, while their earnings allow them to move above the subsistence level. Second, the cost of subsistence for a family, when transformed to current dollars, is very similar to the present-day poverty line as defined by the World Bank at $\$ 1.25$ per day. Hence, a subsistence ratio equal to one implies that a family is living on the edge of the poverty line. As such, the ratio measures the standard of living in a particular moment of time as a multiple of the poverty line. ${ }^{63}$

The computation of the subsistence ratio for Barcelona allows us to analyse the evolution of living standards in the period under study in a European comparative perspective (Figure 2 and Table 4). In previous studies a clear divergent pattern within Europe has been found. ${ }^{64}$ While cities of north-west Europe, such as London and Amsterdam, enjoyed a high standard of living (around three to four times above the subsistence level), the cities of continental Europe experienced a continuous decline over time. By the end of the eighteenth century, the subsistence ratio was around one, and thus the yearly earnings of construction labourers placed them close to the poverty line. In this case, the evolution of Barcelona follows that of the continental cities. Thus, when the cost of living is considered in relation to the computation of the subsistence basket, the relatively favourable position found for Barcelona, in terms of nominal wages, vanishes.

Figure 2

Table 4

${ }^{63}$ Allen, Murphy, Schneider, 'Colonial origins'; Allen, 'Poverty lines'.

${ }^{64}$ Allen, British Industrial Revolution. 
On the basis of these results, can the early adoption of the spinning jenny in Catalonia be explained in terms of relative factor prices? A recently expressed view in the debate as to why the Industrial Revolution began in Britain claims that the profitability of new technologies was a key variable. According to this line of argument, inventions affect the input requirements of production, and technologies generate a bias in the use of factors. ${ }^{65}$ Specifically, in comparison with the spinning wheel, the spinning jenny increased capital requirements while reducing labour needs. Thus, not only do we need to examine the average wage levels of a particular economy, we also need to study the structure of relative prices, including those of both labour and capital. How did Barcelona perform in comparison with England and France, Europe's two main cotton producers in Europe at that time, in terms of the prices of labour and capital?

Allen constructs a ratio between labour and capital prices, taking nominal wages in the construction sector and computing the price of capital $(r)$ based on the following expression: ${ }^{66}$

$$
r=P_{K}(i+d)
$$

where $i$ is the interest rate, $d$ is the depreciation rate, and $P_{K}$ denotes the price of capital goods as a geometric average of the prices of labour and building materials (iron, bricks and soft-wood). The interest rates included in the exercise were obtained from Homer and correspond to long-term interest rates paid by the British and the French governments. ${ }^{67}$

\footnotetext{
${ }^{65}$ Allen, British Industrial Revolution.

${ }^{66}$ Allen, 'Industrial Revolution'. From an economic theory point of view, Acemoglu, 'Directed technical change'; idem, 'When does labor scarcity'.

${ }^{67}$ Homer, History, pp. 117, 126 and 157; Homer and Sylla, History, pp. 157-8, 170, 192 and 217. British interest rates correspond to the annual average of the yields of long-term British government securities (3\% annuities and consols). In turn, French data refer to long-term interest on government credit (rentes), beginning in 1756. It is argued that the French rentes were similar in structure to the British consols (Homer and Sylla, History, p. 216).
} 
In the spirit of Allen we explore the relative prices for labour and capital. ${ }^{68}$ However, in gathering the information for Barcelona we run into various problems. First, information for the prices of building materials in Barcelona in that period is incomplete. In order to solve this drawback, as a first approximation, we compute a raw ratio between nominal wages and nominal interest rates. Second, to the best of our knowledge, data on the interest rates paid by government bonds in Spain in the late eighteenth century are not available. We use, by way of alternative, the short-term commercial interest rates or descuentos provided by MaixéAltés. ${ }^{69}$ Arguably, these interest rates are, in fact, more appropriate for the calculations undertaken in this exercise given that they are the rates that merchants and manufacturers would have had to pay in Catalonia to obtain credit, and thus they reflect more accurately the cost of capital for those involved in manufacturing activities. Unfortunately, while these interest rates are particularly suitable, they hinder the comparison of ratios between Barcelona and the other cities considered. The results are presented for London (England), Strasbourg (France) and Barcelona (Catalonia). The data for nominal wages in the first two cities are drawn from Allen, ${ }^{70}$ while for Barcelona the source used is Feliu as detailed in the previous section. ${ }^{71}$ Figure 3 depicts the ratio for the aforementioned cities, with London in 1776 being set equal to 1 .

Bearing in mind then that the interest rates for Barcelona do not correspond to public debt but to the interest rates charged to merchants, the results show Barcelona's ratio to be well below the levels reached in London. Therefore, at an aggregate level, no incentive appears to have been present in Catalonia for labour substitution. However, given that the price of capital in London (and Strasbourg) is captured by the long-term interest rates in

\footnotetext{
${ }^{68}$ Allen, 'Industrial Revolution'.

${ }^{69}$ Maixé-Altés, 'Coyuntura'. We thank Joan Carles Maixé-Altés for kindly providing us with the data.

70 Allen, 'Great divergence'.

${ }^{71}$ Feliu, Precios y salarios, vol. I and II.
} 
government bonds this could be considered as overestimating the ratio. Even so, the ratio for Barcelona is comparable to the values obtained for Strasbourg.

Figure 3

Given the limitations of the previous exercise, in order to gain further insights into the role played by the relative prices of production factors in the adoption of technology, an alternative approximation is suggested. Instead of focusing on the general prices for labour and capital at the aggregate macro-level for different economies, we rely on information from the cotton textile sector in the late 1780s for England, France and Catalonia. Once again we compute a raw ratio between the price of labour and the price of capital for the specific task of cotton spinning. In so doing, we take the daily wage paid to a spinner as the price of labour; for the price of capital we use the purchase price of a spinning jenny, i.e., the investment cost faced by the producer. The data for England and France are drawn from Allen and Gragnolati, Moschella and Pugliese. ${ }^{72}$ Spinners earned $6.25 d$ per day in England and 9 sous tournois in France. The price of a 24-spindle jenny for cottage use is estimated at 70 shillings in England and 140 livres tournois in France. For Catalonia, the spinners' wage and the price of a jenny (in sous) are obtained from Garcia Balañà and Okuno. ${ }^{73}$ A 36-spindle jenny, the most common machine used in Catalonia at that time, would have cost around 900 sous. As the number of spindles is greater than that on the machines in England or France, our calculations tend to push the ratio between wages and the price of capital downwards for Catalonia.

The results of this exercise can be consulted in Table 5. First, the relative prices of labour and capital show that there were significant differences between England and France,

\footnotetext{
72 Allen, 'Industrial Revolution', p. 619; Gragnolati, Moschella, Pugliese, 'Spinning jenny and the guillotine', Table 2.

${ }^{73}$ Garcia Balañà, Fabricació; Okuno, 'Entre la llana'.
} 
as established in previous research. The wages relative to the cost of capital in France were less than half those recorded in England. It is these significant differences that are at the heart of the explanation as to why the Industrial Revolution occurred in Britain. The high price of labour in England relative to that of capital seems to explain why English producers adopted the new machines that allowed them to substitute the more expensive factor of production (labour) and to use the cheaper one (capital). Second, the wage/capital ratio for Barcelona is high, similar in fact to that recorded in England (89.6\%). Based on these results it seems that Catalan producers, in common with their English counterparts, may likewise have had an incentive to mechanise production, showing themselves to be more enthusiastic about new cotton spinning technologies than were the French producers.

Table 5

Why was the value of the Catalan wage/capital ratio for cotton spinning more than twice as high as that of the French ratio? The figures in grams of silver (Table 5) show that the jenny was only slightly cheaper in Catalonia than in France, so that the difference in the ratio is attributable to the higher Catalan wages. Since spinning jennies were constructed by local carpenters, the relatively low price of the spinning machines can be explained as a result of a 'Marshallian' concentration of skilled carpenters around the high number of cotton manufacturers and calico printers in Barcelona. ${ }^{74}$ However, it is the relatively high wages earned by spinners that seems to push the Catalan ratio close to British values. Indeed, available evidence for wages supports this finding. Two features nonetheless should be mentioned: a daily wage of 6 sous for spinners is actually capturing a lower bound; and, importantly, a similar wage could be commanded by a spinner working in the rural villages of inner Catalonia as that by a spinner in Barcelona. ${ }^{75}$

\footnotetext{
${ }^{74}$ An illustration of the role played by a skilled carpenter in the construction of the first jennies in Catalonia can be found in Thomson, 'Transferring'.

75 This is not surprising, given the integration of the rural-urban labour markets in Catalonia in the last decades of the eighteenth century, as Mora-Sitjà has explained (Mora-Sitjà, 'Labour market').
} 
Thus, Catalan spinning in the 1780s had high nominal wages and relative factor prices similar to those recorded in Britain. Although Catalonia was not a high wage economy, cotton spinners could have achieved a better standing in terms of wages. Spinners were mainly women who earned half the wage of a construction labourer, while their English counterparts received just a quarter of the British construction labourer's wage (2.9 vs. 11.9 in grams of silver). Thus, if a comparison is drawn with England, at first sight it might seem that Catalan spinners were relatively well paid. Yet, the best way to compare earnings is to rely once again on real wages. The determination of the subsistence ratio as in section 3 gives a wage for English and Catalan spinners of 0.87 and 0.80 , respectively (Figure 4). While the real wage of an English spinner was only 8.75 per cent higher than a Catalan spinner's wage, the wage of an English construction labourer in the second half of the eighteenth century more than doubled the Catalan wage. Hence, in the context of the Catalan economy, spinners were very well paid.

\section{Figure 4}

In our view, this difference reflects the bottleneck in cotton spinning during these years. As mentioned in section 2, printed calico exports boomed after 1783 and this coincided with a process of import substitution of cotton yarn. The increase in raw cotton imports entering the port of Barcelona is evidence of this increase in cotton spinning. In 1783, raw cotton imports totalled 223,900 pounds. ${ }^{76}$ Ten years later, in 1793 , the total had risen almost five-fold $(1,098,433$ pounds). All this raw cotton had to be spun in Catalonia, which resulted in a high demand for spinners as well as high wages for spinners and, hence, there was a strong incentive to substitute labour by adopting the spinning jenny.

\footnotetext{
76 Thomson, 'Explaining', p. 714.
} 
In the light of these results, can we conclude that the relative prices of production factors played a role in the early adoption of the spinning jenny across Catalonia? Here, the issue at stake is just how profitable it would have been for Catalan producers to adopt the spinning jenny in the early stages of industrialisation. The detailed information available for the Catalan case allows us to conduct a precise micro-economic analysis to examine the profitability of the first jennies installed in Catalonia. The spinning jenny was first introduced in 1786 and was widely adopted through the 1790s, which suggests that the spinning jenny was profitable in Catalonia during this period. Allen has shown that jennies were profitable for contemporary English cottages but not for their French counterparts. ${ }^{77}$ Below, we seek to apply the same analysis to the Catalan case in order to test whether or not his interpretation of the Industrial Revolution allows us to explain what happened south of the Pyrenees.

In Allen's model the decision makers are domestic producers who live in cottages and spend some of their time spinning cotton for weavers or merchants. The question is whether or not these domestic producers deemed it profitable to buy a 24-spindle jenny because of an increase in labour productivity; that is, whether the reduction in labour costs offset the sum of the price of a jenny plus a normal profit rate. The rate of return of the investment is obtained by solving the following equation:

$$
J=\sum(w \Delta L-m) /(1+r)^{t}, \text { with } t=1,2, \ldots n
$$

where $J$ is the price of a jenny, $w$ the daily wage of a spinner, $\Delta L$ the number of days of labour saved per year, $m$ the cost of maintenance of the jenny and $r$ is the internal rate of return to be calculated. The labour saved is computed as:

\footnotetext{
${ }^{77}$ Allen, 'Industrial Revolution'.
} 


$$
\Delta \mathrm{L}=\mathrm{YD}(1-1 / \mathrm{P})
$$

where $Y$ is the number of working days in a year, $D$ the part of a working day devoted to spinning and $P$ the relative productivity of the new technology compared to the former (i.e., the spinning wheel). To solve this equation, several assumptions must be made. First, the time span $t$ is set at ten years, representing the life expectancy of a jenny. The cost of maintenance $m$ is assumed to be 10 per cent of the purchase price of the jenny and the number of working days per year $(Y)$ to be $250 .{ }^{78}$ As for $D$ and $P$, several scenarios are examined. It is believed that cottage spinners devoted between 30 and 50 per cent of their working time to spinning, with $D$ being equal to $0.3,0.4$ or 0.5 in alternative calculations. For example, if we assume that spinners devoted 40 per cent of their working time to spinning, then the 250 working days are computed as 100 full time equivalent days. On the other hand, contemporary testimonies indicate that the labour productivity of the 24-spindle jenny was between two and four times that of the spinning wheel. In this case, with a typical $P$ equal to 3 , up to 66.6 per cent of the labour would be saved.

Once all these parameters have been fixed, the two variables that make the spinning jenny profitable or unprofitable in each country are those included in Table 5, that is, the purchase price of a jenny $(J)$ and the daily wage of a spinner $(w)$. Since Allen's interpretation is concerned with relative factor prices, the higher the 'wage/jenny price' ratio, the greater the probability of it being profitable to adopt the spinning jenny. Our results in the previous section show that the Catalan ratio is much closer to the British than to the French ratios, being only 10 per cent lower than the former. Indeed, the Catalan internal rates of return under different scenarios are quite similar to those found in Britain, as can be seen in Table 6 .

\footnotetext{
78 In the specific case of Catalonia, Ildefons Cerdà estimated that in 1856 labourers in calico-printing factories worked 249 days a year. Quoted in Mora-Sitjà, 'Labour market', p. 165.
} 
If we consider, as Allen does, a 15 per cent profitability threshold, only in the worst case scenario was buying a jenny not a profitable investment in Catalonia in the late 1780s (as it was also in Britain). By contrast, as Allen has shown, only in the best case scenario was the jenny profitable in France in these same years. ${ }^{79}$

Table 6

A key assumption in the model is that the gains in labour productivity are analysed as a cost reduction, not as an output increase. Hence, when a spinner bought a jenny with which she could produce three times as much yarn per hour as with a wheel, the spinner did not triple her production but rather produced the same amount and saved the two thirds of her time previously devoted to spinning. This assumption has been criticised by Gragnolati, Moschella and Pugliese. ${ }^{80}$ They argue that it is not economical to make an investment in a technology with increasing returns to scale and at the same time to reduce the quantity of labour applied. If a cottager made an effort to buy a jenny, she would try to make it profitable by using it intensively, increasing her working time rather than reducing it. In fact, they demonstrate that by maintaining the quantity of labour and, thus, increasing production, the jenny would have been profitable in France in all but the worst case scenario. Thus, they conclude that Allen's model is incomplete and factor prices alone cannot explain the delay in the adoption of the spinning jenny in France. They develop a model in which factor prices and the size of demand are combined to predict precisely the timing of the adoption of the jenny both in Britain and France.

Allen's answer to this critique is to stand by his assumption that spinners had a target level of consumption, in the same way that farm labourers did in earlier centuries under the

\footnotetext{
${ }^{79}$ For a critical assessment of this methodology, see Crafts, 'Explaining'.

${ }^{80}$ Gragnolati, Moschella, Pugliese, 'Spinning jenny and the Industrial Revolution'; idem, 'Spinning jenny and the guillotine'.
} 
putting-out system: when the daily wage rose, they worked less; when their wages fell, they worked more. Thus, it is plausible that spinners would have reduced their working time when they reached a similar level of production and income by employing less time.$^{81} \mathrm{It}$ is our belief that Allen is right in making this assumption, although we understand the Italian scholars' concern for the labour intensification issue, because it too may have played a key role in the adoption of the spinning jenny in Catalonia and it links up with the fundamental debate about the emergence of the factory system in the Industrial Revolution.

The first spinning jenny, or at least knowledge of it, reached Barcelona in 1784 via to two French machine-makers, Pontet and Pradel. In 1787, the Royal Company decided to establish a mill in Barcelona with the 14 jennies. Garcia Balañà undertook a detailed study of the Company's records over the following years. ${ }^{82}$ In 1791, working six days per week, the average weekly production of one spinner was $5.4 \mathrm{lb}$, that is, $0.9 \mathrm{lb}$ per day, well below the target set by the company in 1788. Garcia Balañà attributes this failure to the fact that the spinners were young girls, most of whom formed part of urban households in which their labour was required on an intermittent, irregular basis. The flexibility they had previously enjoyed as they moved between the house, the workshop and the mill was essential for the urban households of which they were members. ${ }^{83}$ However, the mill's profitability depended on an increase in throughput and on the lengthening of the time the spinners spent working, in short, on making sure that a full-time working day was achieved. With labour intensification and the growth in production, the profitability of the capital investment was guaranteed, precisely the outcome that Gragnolati, Moschella and Pugliese expect from a person who bought a jenny. ${ }^{84}$ Cottage spinners might have had their target level of consumption, but the Royal Company owners certainly sought to maximise their profits. The Royal Company mill, however, was unable to

\footnotetext{
${ }^{81}$ Allen, 'Spinning jenny'.

${ }^{82}$ Garcia Balañà, Fabricació, 166-219.

${ }^{83}$ Carbonell, Sobreviure, pp. 121-4, quoted in Garcia Balañà, Fabricació, p. 187.

${ }^{84}$ Gragnolati, Moschella, Pugliese, 'Spinning jenny and the Industrial Revolution'.
} 
break the economic logic of the urban households, be it by imposing disciplinary codes or by offering incentives; the fathers of the young spinners retained greater power over the girls than the mill foremen. The time of the factory system for cotton spinning had not yet arrived. In fact, the Royal Company decided to close its mill soon afterwards, probably not much later than the end of 1792 , and to buy the yarn in the market. ${ }^{85}$

Yet, this episode did not mark the end of the spinning jenny in Catalonia; it was no more than the beginning. There is evidence that as early as 1791 there were at least 108 jennies in Catalonia and that they then spread very quickly throughout the 1790s in Barcelona, as well as in the region's manufacturing towns and villages, and in the countryside. ${ }^{86}$ The booming demand for printed calicoes and the need to provide all the yarn from home led to the rapid expansion of cotton spinning and the adoption of new machines in Catalonia. Yet, the jennies did not change the scale or the geographical location of spinning because they were powered by hand ${ }^{87}$ In fact, most of them were installed in homes or in small workshops. We have already shown that the spinning jenny was profitable for Catalan domestic producers at the end of the 1780 s by replicating Allen's analysis; however, the abundance of available data allows us to conduct a slightly different test for the second half of the 1790s. But to do so we need to return once more to the Royal Company.

Following the closure of its mill, the Royal Company stocked up on yarn from domestic producers in Barcelona and its hinterland. This time, they tried not to have to depend on the middlemen of the old putting-out system and so they established direct links with their suppliers. Garcia Balañà reports that in 1797 the Company decided to lease jennies to various

\footnotetext{
${ }^{85}$ Garcia Balañà, Fabricació.

${ }^{86}$ Sánchez, 'Berguedanes'.

87 Sánchez, 'Orígens'.
} 
domestic producers and small workshops in Barcelona. ${ }^{88}$ The terms of the agreement were as follows: the owner of the jenny remained the Company, but the spinning was to be done at the spinner's home or domestic workshop. In exchange for the use of the Company's jenny, the piece rate fell from 12 to 7.5 sous per $\mathrm{lb}$. But given the increase in labour productivity, the spinner could afford a piece rate reduction of that amount. In contrast with Allen's model for the cottage jenny, here the investor was the Company, not the spinner, and the productivity increase was for the benefit of the investor obtained in return for a reduction in the piece rate. In this context, we can calculate the internal rate of return of this investment using the following expression:

$$
J=\sum Q\left(p^{w}-p^{j}\right)-m /(1+r)^{t}
$$

where the summation is over $t=1,2, \ldots n ; Q$ is the annual production of yarn, $p^{w}$ is the piece rate with the wheel, $p^{j}$ the piece rate with the jenny and $m$ the additional maintenance costs associated with the jenny. Fortunately, actual data are available for the annual production $(Q)$ of several spinners that worked for the Company in 1798 , so no assumptions about the number of days worked and the labour intensity have to be made in this case. It is our contention that this is an interesting contribution given that Crafts questioned the robustness of Allen's analysis on the basis of the change in results when the assumptions for the parameters in the previous equation are modified..$^{89}$ In 1797, 36-spindle jennies were cheaper than they were by the end of the 1780 s, costing just 450 sous. However, the Company files do not specify which kind of jennies were leased out. We make, therefore, a conservative assumption of 60 -spindle jennies with a price in 1797 of 1,200 sous. ${ }^{90}$ Thus, we take $J=1.200$,

\footnotetext{
${ }^{88}$ Garcia Balañà, Fabricació.

${ }^{89}$ Crafts, 'Explaining'; Allen, 'Spinning jenny'.

${ }^{90}$ Conservative in the sense that we assume a high price for the jennies.
} 
$m=120, p^{w}=12$, and $p^{j}=7.5$. In Table 7 the internal rates of return for three domestic spinners or small workshops are presented.

Table 7

Thus, it seems clear that this kind of investment was highly profitable for the Company. Garcia Balañà stresses that some of the suppliers were not single spinners but small family workshops overseen by a man. In fact, the same households that thwarted the efforts of the Company's mill by interfering in the regular supply of young female labour, now leased the jennies and produced yarn at home. These workshops became specialised in cotton spinning and were more efficient in terms of labour intensification than had previously been possible under the mill's regulations. In short, family hierarchies and gender roles were still more powerful than the factory system at the time of the jenny. However, in the case of the water frame and the mule jenny, technology that required the use of water or steam energy and where economies of scale acquired greater significance, the factory system finally succeeded.

\section{VI}

The roots of the exceptional experience that represents the Catalan industrialisation in the late eighteenth and nineteenth centuries lay in the early integration of its economy in international trade during the seventeenth and eighteenth centuries and the development of an increasingly capitalist economy. Moreover, a highly distinctive cotton manufacturing sector developed in the region after 1736 and the spinning jenny was widely adopted in the 1790 s. In common with historical experiences elsewhere, spinning machines were introduced by the calico manufacturers, who saw an opportunity to increase their profit margins by vertically integrating their activities and producing the cotton yarn themselves. Against this backdrop, 
our study focuses on this case of early industrialisation as we analyse the price structure of the factors of production associated with technology adoption and diffusion, taking as our framework of reference Allen's studies of the British Industrial Revolution. ${ }^{91}$

The first contribution of the paper is the construction it undertakes of long-term annual real wage series for Barcelona between 1500 and 1808, based on the subsistence ratio. In this way, the Catalan experience can now be incorporated within the global history of wages and prices that in recent years, within the broader context of the 'Great Divergence' debate, has provided information for a growing pool of cities around the world in the early modern period. Our results show that living standards in Barcelona adhered to the typical continental pattern. Furthermore, in the second half of the eighteenth century Catalonia was not a high wage economy, in the way that Britain or the Low Countries were, although it did occupy a respectable position behind this front line. In addition, the structure and evolution of the relative prices of the production factors at the aggregate level of the Catalan economy were comparable to those in other areas of western Europe (e.g., France) but were less favourable in terms of labour substitution when compared with Britain.

However, when the focus is shifted to the cotton spinning sector, where technological changes were taking place, our results point to different conclusions. At the end of the $1780 \mathrm{~s}$, the ratio between the spinners' wages and the price of purchasing a jenny in Catalonia was below but close to that in Britain and well above the French ratio. Thus, relative prices in Catalonia at that time favoured the demand for new technologies to substitute labour, a more expensive production factor than capital. Further, a micro-level analysis confirms the acceptable rate of return of investing in the purchase of spinning jennies. The machines were commercially profitable. Catalan producers had incentives to mechanise production, as was

\footnotetext{
${ }^{91}$ Allen, British Industrial Revolution; idem, 'Industrial Revolution'.
} 
the case for British producers, and this led to the adoption and diffusion of this early technology of the Industrial Revolution across Catalonia. Hence, a British macro-invention that changed factor proportions by saving labour was widely adopted in the Catalan textile sector.

This result can be explained by the exceptional conjuncture of circumstances enjoyed by the calico-printing sector in Barcelona in the last decades of the eighteenth century. Production and exports boomed after 1783 and, at the same time, an accelerated process of yarn import substitution was taking place. Cotton spinning was displacing wool in many peasant homes in Central Catalonia and the Pyrenean foothills, and new initiatives were being taken in the city of Barcelona, but there was still a major bottleneck that left the sector in great need of large amounts of cotton yarn. This high demand translated into high wages for cotton spinners and, hence, created a strong incentive to incorporate labour-saving technology, the spinning jenny. Although at the macro-level real wages were not especially high in Catalonia, at the micro-level, the key sector, cotton spinning, was booming. This interpretation fits well with Crafts' view of the British Industrial Revolution where technological changes were concentrated in a number of dynamic sectors and it took a long time before the effects were perceived at the macro-level, thanks to an increase in productivity.$^{92}$

In the first decades of the nineteenth century the cotton sector in Catalonia had to overcome a number of difficulties in order to advance after what had been a promising start. The new macro-inventions emanating from the British Industrial Revolution in the cotton sector used natural resources that were both scarce and expensive in Catalonia, namely, water and coal. The price structure in Catalonia favoured the adoption of the spinning jenny. The new technologies, including Arkwright's water frame and Crompton's mule, being energy-

\footnotetext{
${ }^{92}$ Crafts, British; idem, 'Forging ahead'.
} 
based, could have created a price structure for the production factors that in this case might not have been so favourable for Catalan producers. Thus, the process of technology transfer slowed down. The high price of energy could be blamed for this outcome. Other authors stress that the British ban on machine exports was also responsible, and only after it had been lifted in 1842 could the Catalan textile industry adopt the technology under the factory system. In any case, the adequacy of the first textile technology and the delay in the adoption of the subsequent technologies would explain why the spinning jenny and its local improvement, the berguedana, had a long life in Catalonia.

This case study of Catalonia also shows that, thanks to the exceptional conjuncture of circumstances in the late eighteenth century, cotton producers were sensitive to factor prices within an institutional framework of lower quality than that which had developed in northwest Europe. The explanation based on the demand for technology can nonetheless be complemented with technology-supply or market size arguments to provide a more complete view of the socio-economic transformations that led Catalonia to an early - albeit one that was not exempt of difficulties - industrialisation and to become the main industrial centre in the Mediterranean throughout the nineteenth century. 


\section{Figures and Tables}

Figure 1. Nominal wages for construction labourers, Europe 1500-1808 (grams of silver per day)

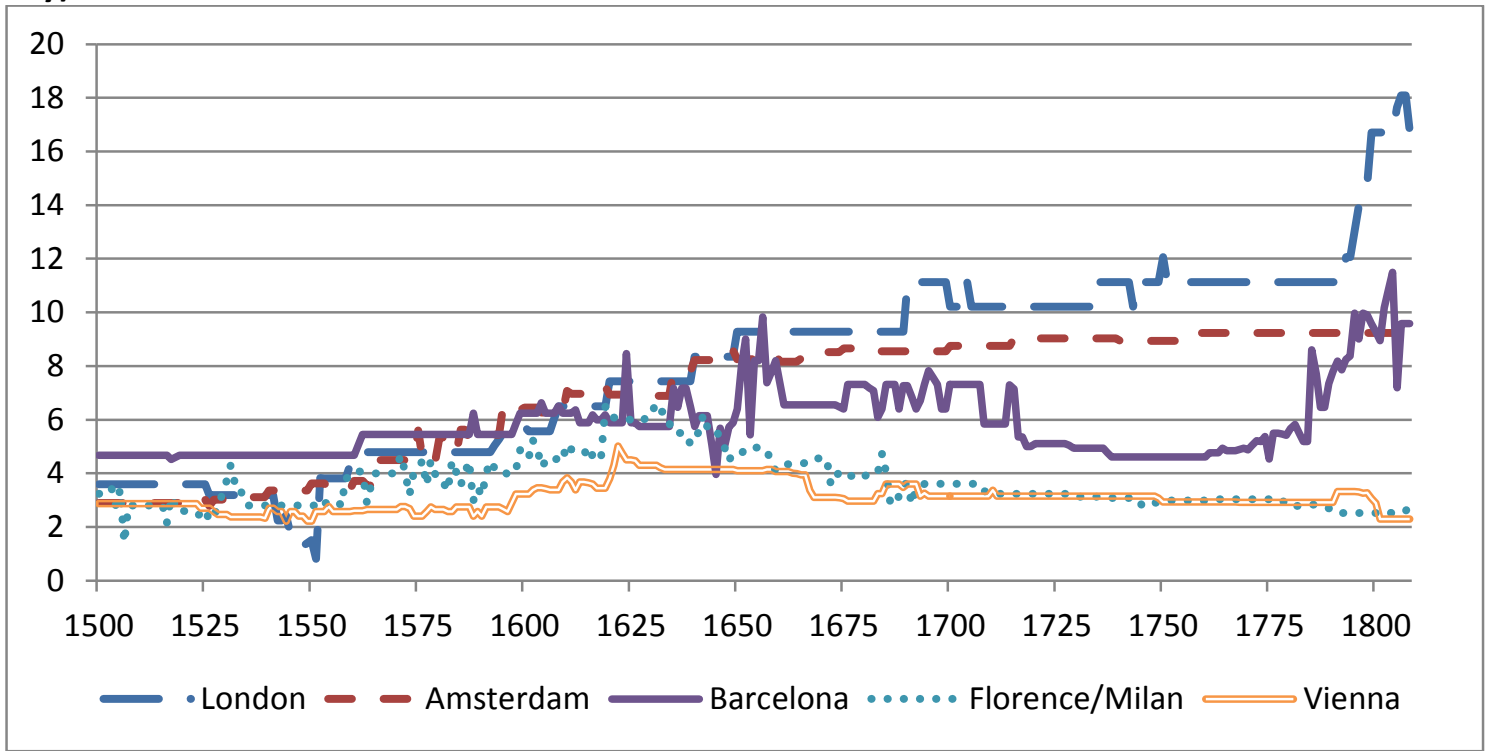

Source: Allen, 'Great divergence'. Florence: 1500-1617; Milan 1618-1808. For Barcelona, see text.

Figure 2. Subsistence ratio for labourers in Europe, 1500-1800 (fifty-year average)

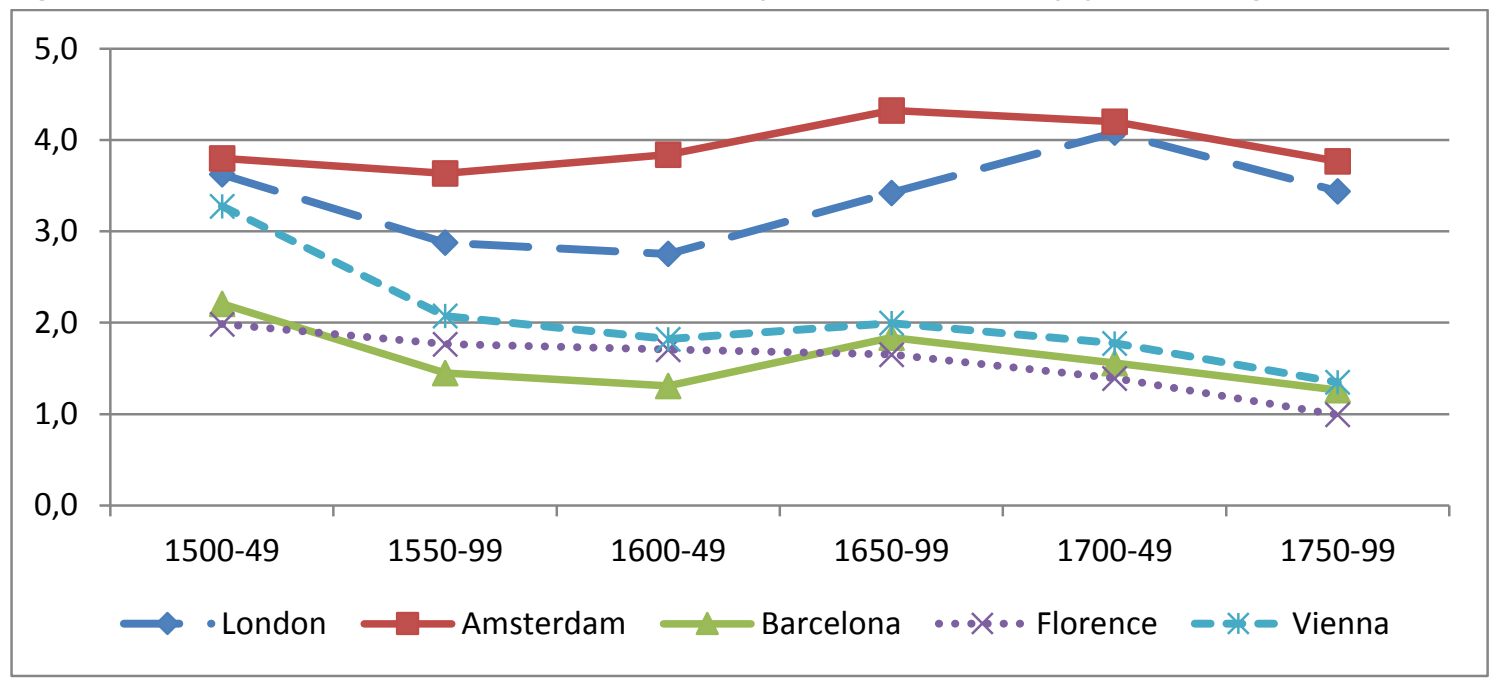

Source: Allen, Murphy, Schneider, 'Colonial origins', EHES Conference, p. 45. For Barcelona, see text. 
Figure 3. Wage relative to price of capital (London 1776=1)

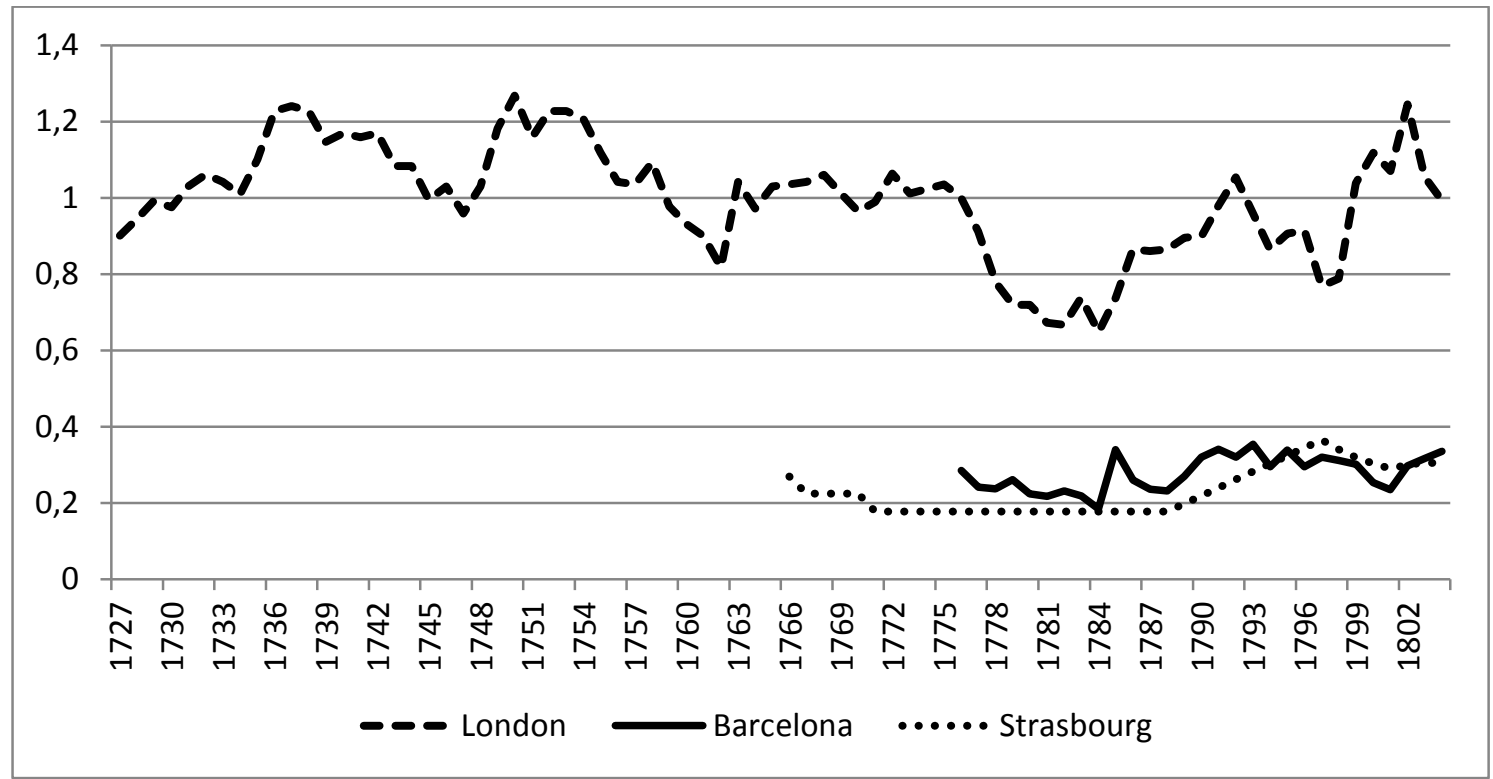

Sources: see text. Data for London and Strasbourg kindly provided by R. Allen.

Figure 4. Labourers' and spinners' real wages (subsistence ratio) in England and Catalonia

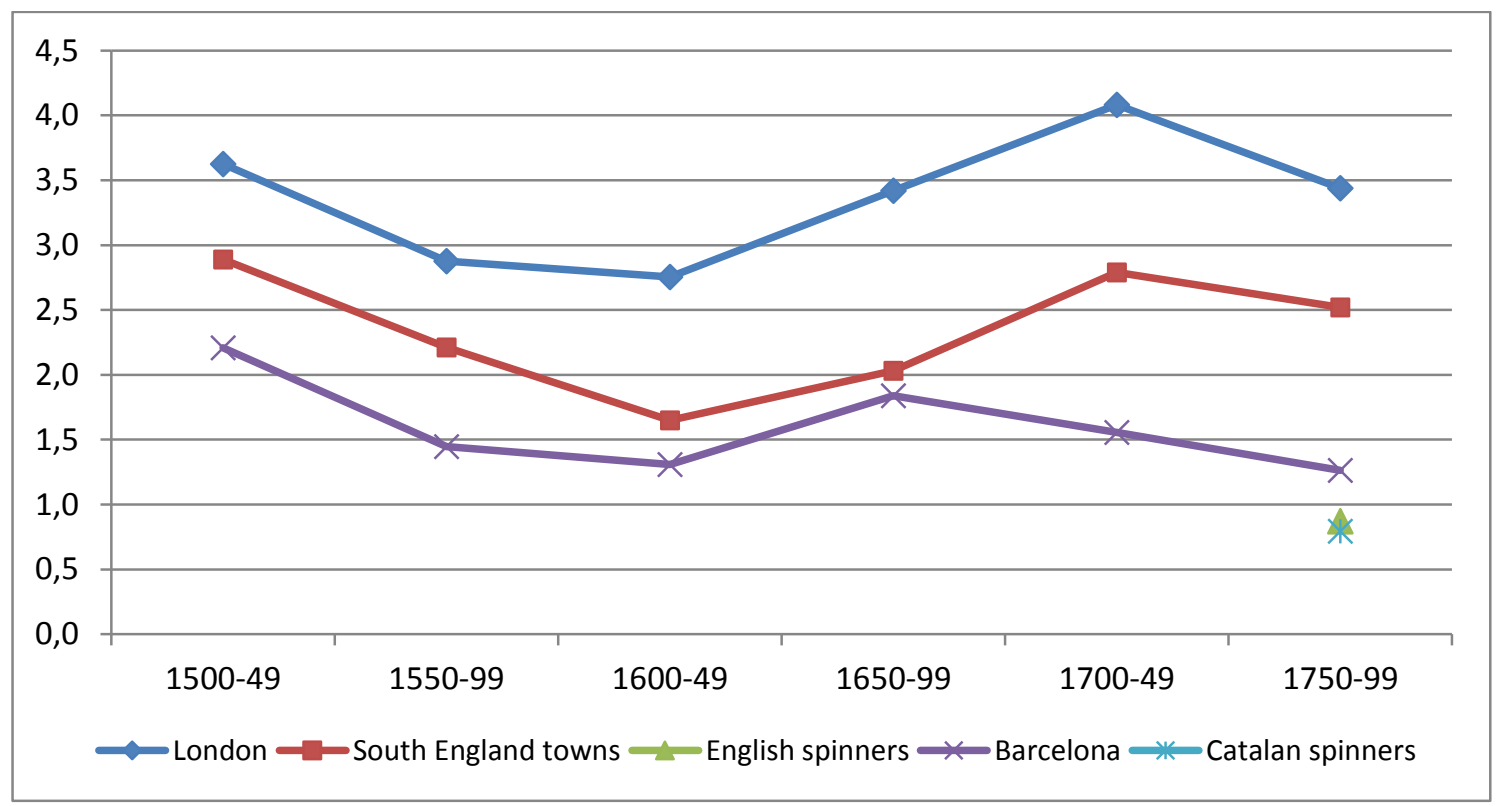

Source: For London and South England towns, Allen, 'Great divergence'; for the rest, see text. Note: the figure is constructed computing the spinners' wages full-time and annually as with the construction labourers. 
Table 1. Nominal wages for construction labourers, Europe 1500-1808 (grams of silver per day)

\begin{tabular}{lccccc}
\hline Averages & London & Amsterdam & Barcelona & Florence/Milan & Vienna \\
\hline $1500-49$ & 3.2 & 3.1 & 4.7 & 2.9 & 2.7 \\
$1550-99$ & 4.6 & 4.7 & 5.3 & 3.8 & 2.6 \\
$1600-49$ & 7.1 & 7.2 & 6.1 & 4.7 & 4.4 \\
$1650-99$ & 9.7 & 8.5 & 7.1 & 4.1 & 3.5 \\
$1700-49$ & 10.5 & 8.9 & 5.5 & 3.2 & 3.2 \\
$1750-99$ & 11.5 & 9.2 & 6.0 & 2.9 & 3.0 \\
$1800-08$ & 17.1 & 9.2 & 9.6 & 2.6 & 2.4 \\
\hline
\end{tabular}

Source: Allen, 'Great divergence'. Florence: 1500-1649; Milan 1650-1849. For Barcelona, see text.

Table 2. Bare-bones subsistence basket of goods

\begin{tabular}{|c|c|c|c|c|c|c|}
\hline & & & \multicolumn{2}{|c|}{$\begin{array}{l}\text { Quantity per person per } \\
\text { year }\end{array}$} & \multicolumn{2}{|c|}{ Calories/day } \\
\hline \multicolumn{7}{|l|}{ Food } \\
\hline & Wheat & & \multicolumn{2}{|c|}{$215 \mathrm{~kg}$} & \multicolumn{2}{|r|}{1,657} \\
\hline & Beans & & \multicolumn{2}{|c|}{$20 \mathrm{~kg}$} & \multicolumn{2}{|r|}{187} \\
\hline & Meat (beef) & & \multicolumn{2}{|c|}{$5 \mathrm{~kg}$} & \multicolumn{2}{|r|}{34} \\
\hline & Olive Oil & & \multicolumn{2}{|c|}{31} & \multicolumn{2}{|r|}{60} \\
\hline \multicolumn{7}{|l|}{ Non-Food } \\
\hline & Soap & \multicolumn{3}{|c|}{$1.3 \mathrm{~kg}$} & & \\
\hline & nen / Canvas & \multicolumn{3}{|c|}{$3 \mathrm{~m}$} & & \\
\hline & Candles & \multicolumn{3}{|c|}{$1.3 \mathrm{~kg}$} & & \\
\hline & Lamp Oil & \multicolumn{3}{|c|}{1.31} & & \\
\hline & Fuel & \multicolumn{3}{|c|}{2 million BTUs } & & \\
\hline \multicolumn{5}{|l|}{ Total } & \multicolumn{2}{|r|}{1,938} \\
\hline \multicolumn{7}{|c|}{$\begin{array}{l}\text { Sources: Allen, British Industrial Revolution, p. 37; Allen, Bassino, Ma, Moll-Murata, Van Zanden, } \\
\text { 'Wages', p. 21; Allen, Murphy, Schneider, 'Colonial origins', EHES Conference, p. } 43 .\end{array}$} \\
\hline \multicolumn{7}{|c|}{$\begin{array}{l}\text { Table 3. Cost of the equivalent bare-bones subsistence baskets, 1500-1800 (grams of } \\
\text { silver/year) }\end{array}$} \\
\hline Averages & London & Amsterdam & Barcelona & Florence & Vienna & Valencia/Madrid \\
\hline $1500-49$ & 67 & 66 & 176 & 99 & 59 & 144 \\
\hline $1550-99$ & 128 & 104 & 306 & 156 & 96 & 324 \\
\hline $1600-49$ & 201 & 152 & 374 & 177 & 180 & 439 \\
\hline $1650-99$ & 220 & 158 & 319 & 129 & 127 & 383 \\
\hline $1700-49$ & 201 & 172 & 282 & 177 & 130 & 328 \\
\hline $1750-99$ & 264 & 202 & 382 & 240 & 165 & 392 \\
\hline
\end{tabular}

Source: Allen, Murphy, Schneider, 'Colonial origins', EHES Conference, p. 44. For Barcelona, see text. 
Table 4. Subsistence ratio for labourers in Europe, 1500-1800

\begin{tabular}{lccccc}
\hline & London & Amsterdam & Barcelona & Florence & Vienna \\
\hline $1500-49$ & 3.62 & 3.80 & 2.21 & 1.99 & 3.28 \\
$1550-99$ & 2.88 & 3.64 & 1.45 & 1.77 & 2.07 \\
$1600-49$ & 2.75 & 3.84 & 1.31 & 1.71 & 1.82 \\
$1650-99$ & 3.42 & 4.33 & 1.84 & 1.65 & 1.99 \\
$1700-49$ & 4.08 & 4.20 & 1.56 & 1.39 & 1.77 \\
$1750-99$ & 3.44 & 3.77 & 1.26 & 0.99 & 1.35 \\
\hline
\end{tabular}

Source: Allen, Murphy, Schneider, 'Colonial origins', EHES Conference, p. 45. For Barcelona, see text.

Table 5. Wage/capital ratio for the textile sector in the late $1780 \mathrm{~s}$

\begin{tabular}{lccc}
\hline & England & France & Catalonia \\
\hline & & & \\
Daily wage $(\mathrm{w})$ & $6.25 \mathrm{~d}$ & $9 \mathrm{st}$ & $6 \mathrm{~s}$ \\
Daily wage in grams of silver $(\mathrm{w})$ & 2.90 & 2.12 & 3.83 \\
Price of a jenny $(\mathrm{J})$ & $840 \mathrm{~d}$ & $2800 \mathrm{st}$ & $900 \mathrm{~s}$ \\
Price of a jenny in grams of silver $(\mathrm{J})$ & 389.75 & 658.14 & 575.01 \\
$(\mathrm{w}) /(\mathrm{J})$ & 0.00744 & 0.00321 & 0.00667 \\
England=100 & 100 & 43.2 & 89.6 \\
& & & \\
\hline
\end{tabular}

Source: Based on Gragnolati, Moschella, Pugliese, 'Spinning jenny and the guillotine', Table 2 and Garcia Balañà, Fabricació, pp. 161-2.

Table 6. Rates of return to buying a spinning jenny in Britain, France and Catalonia

\begin{tabular}{ccccc}
\hline $\begin{array}{c}\text { Relative } \\
\text { Productivity }\end{array}$ & $\begin{array}{c}\text { Per cent } \\
\text { Full-Time }\end{array}$ & $\begin{array}{c}\text { Britain } \\
\text { (per cent) }\end{array}$ & $\begin{array}{c}\text { Catalonia } \\
\text { (per cent) }\end{array}$ & $\begin{array}{c}\text { France } \\
\text { (per cent) }\end{array}$ \\
\hline 2 & 0.5 & 34.6 & 29.9 & 0.2 \\
2 & 0.4 & 24.0 & 20.3 & -8.2 \\
2 & 0.3 & 12.3 & 9.4 & -21.7 \\
3 & 0.5 & 51.2 & 44.8 & 10.7 \\
3 & 0.4 & 38.0 & 32.9 & 2.5 \\
3 & 0.3 & 24.0 & 20.3 & -8.2 \\
4 & 0.5 & 59.2 & 52.0 & 15.3 \\
4 & 0.4 & 44.7 & 38.9 & 6.8 \\
4 & 0.3 & 29.4 & 25.2 & -3.7 \\
\hline
\end{tabular}

Source: Allen, 'Industrial Revolution', Table 1; and Garcia Balañà, Fabricació, pp.161-2. 
Table 7. Rates of return to leasing a spinning jenny in Catalonia in $\mathbf{1 7 9 8}$

\begin{tabular}{lccc}
\hline Spinner's name & No. Jennies & Q per jenny & TIR \\
\hline & & (in lb) & (in \%) \\
Francesca Costa & 1 & 142.2 & 42.0 \\
Francesca Pasqual & 1 & 154.2 & 46.8 \\
Josepa Serra/Paula Arnau & 2 & 220.6 & 72.4 \\
\hline
\end{tabular}

Source: Garcia Balañà, Fabricació, Table 3.3 and pp. 197-8. 


\section{Footnote references}

Acemoglu, D., 'Directed technical change', Review of Economic Studies, 69 (2002), pp. 71-89.

Acemoglu, D., 'When does labor scarcity encourage innovation?', Journal of Political Economy, 118 (2010), pp. 1037-78.

Allen, R.C., 'The Great Divergence in European wages and prices from the middle ages to the First World War', Explorations in Economic History, 38 (2001), pp. 411-77.

Allen, R.C., The British Industrial Revolution in global perspective (Cambridge, 2009).

Allen, R.C., 'The Industrial Revolution in miniature: the spinning jenny in Britain, France and India', Journal of Economic History, 69 (2009), pp. 901-27.

Allen, R.C., 'The spinning jenny: a fresh look', Journal of Economic History, 71 (2011), pp. 461-4.

Allen, R.C., 'The high wage economy and the Industrial Revolution: a restatement', Discussion Papers in Economic and Social History, 115 (2013), University of Oxford.

Allen, R.C., 'Poverty lines in history, theory, and current international practice', Department of Economics Discussion Papers, 685 (2013), University of Oxford.

Allen, R.C., Bassino, J.P., Ma, D., Moll-Murata, C., Van Zanden, J.L., 'Wages, prices and living standards in China, 1738-1925: in comparison with Europe, Japan, and India', Economic History Review, 64 (2011), pp. 8-38.

Allen, R.C., Murphy, T.E., Schneider, E.B., 'The colonial origins of the divergence in the Americas: a labour market approach', Paper presented at the $9^{\text {th }}$ EHES Conference in Dublin (2011).

Allen, R.C., Murphy, T.E., Schneider, E.B., 'The colonial origins of the divergence in the Americas: a labour market approach', Journal of Economic History, 72 (2012), pp. 863-94. 
Bassino, J.P., Ma, D., 'Japanese unskilled wages in international perspective, 1741-1913', Research in Economic History, 23 (2006), pp. 229-48.

Broadberry, S., Gupta, B., 'The early modern great divergence: wages, prices and economic development in Europe and Asia, 1500-1800', Economic History Review, 59 (2006), pp. 231.

Carbonell, M., Sobreviure a Barcelona: dones, pobresa i assistència al segle XVIII (Vic, 1997).

Clark, G., A farewell to alms: a brief economic history of the world (Princeton, 2007).

Crafts, N.F.R., British economic growth during the Industrial Revolution (Oxford, 1985).

Crafts, N.F.R., 'Forging ahead and falling behind: the rise and relative decline of the first industrial nation', Journal of Economic Perspectives, 12 (2) (1998), pp. 193-210.

Crafts, N.F.R., 'Explaining the first Industrial Revolution: two views', European Review of Economic History, 15(1) (2011), pp. 153-68.

De Vries, J., The Industrious Revolution. Consumer behavior and the household economy, 1650 to the present, (New York, 2008).

Drelichman, M., 'The curse of Moctezuma: American silver and the Dutch disease', Explorations in Economic History, 42 (2005), pp. 349-80.

Farnie, D.A., 'The role of merchants as prime movers in the expansion of cotton industry, 17691990', in Farnie, D.A., Jeremy, D.J, eds., The fibre that changed the world: the cotton industry in international perspective, 1600-1990s, Oxford (2004), pp. 15-55.

Feliu, G., Precios y salarios en la Cataluña moderna. Volumen I: Alimentos (Madrid, 1991).

Feliu, G., Precios y salarios en la Cataluña moderna. Volumen II: Combustibles, productos manufacturados y salarios (Madrid, 1991). 
Ferrer, L., Pagesos, rabassaires $i$ industrials a la Catalunya central, segles XVIII-XIX (Barcelona, 1987).

Ferrer, L., 'Bergadanas, continuas y mules. Tres geografías de la hilatura del algodón en Cataluña, 1790-1830', Revista de Historia Económica, 22 (2004), pp. 337-86.

Garcia Balañà, A., La fabricació de la fàbrica. Treball i política a la Catalunya cotonera, 17841874 (Barcelona, 2004).

Gragnolati, U., Moschella, D., Pugliese, E., 'The spinning jenny and the Industrial Revolution: a reappraisal', Journal of Economic History, 71 (2011), pp. 455-60.

Gragnolati, U., Moschella, D., Pugliese, E., 'The spinning jenny and the guillotine: technology diffusion at the time of revolutions', Cliometrica, 8 (2014), pp. 5-26.

Habbakuk, H.J., American and British technology in the nineteenth century: the search for labour-saving inventions (Cambridge, 1962).

Hamilton, E.J., War and prices in Spain: 1651-1800 (Cambridge, 1947).

Hamilton, E.J., American treasure and the price of revolution in Spain, 1501-1650 (New York, 2nd edn., 1965).

Homer, S., A history of interest rates (New Brunswick, 2nd edn., 1977).

Homer, S., Sylla, A history of interest rates (New Brunswick, 1963).

Humphries, J., 'The lure of aggregates and the pitfalls of the patriarchal perspective: a critique of the high wage economy interpretation of the British industrial revolution', Economic History Review, 6 (2012), pp. 693-714.

Landes, D.S., The unbound Prometheus: technological change and industrial development in Western Europe from 1750 to present (Cambridge, 1969). 
Maixé-Altés, J.C., 'La coyuntura financiera en Barcelona a finales del Antiguo Régimen: el mercado de efectos, 1776-1808, Revista de Historia Industrial, 12 (1997), pp. 181-203.

Marfany, J., 'Is it still helpful to talk about proto-industrialization? Some suggestions from a Catalan case study', Economic History Review, 63 (2010), pp. 942-73.

Marfany, J., Land, proto-industry and population in Catalonia, c. 1680-1829: an alternative transition to capitalism? (Farnham, 2012).

Marx, K., Das Kapital. Kritik der politischen oekonomie (Hamburg, 1867).

Mokyr, J., The enlightened economy: the economic history of Britain, 1700-1850 (2009).

Mora-Sitjà, N., 'Labour and wages in pre-industrial Catalonia', Discussion Papers in Economic and Social History, 45 (2002), University of Oxford.

Mora-Sitjà, N., 'Labour market integration in a pre-industrial economy: Catalonia, 1772-1816', Oxford Economic Papers, 59 (2007), pp. 156-77.

Mora- Sitjà, N., 'El primer proletariat català. Mà d'obra i relacions laborals a les fabriques d'indianes de Barcelona', Barcelona Quaderns d'Història, 17 (2011), pp. 237-52.

Nadal, J., El fracaso de la Revolución Industrial en España, 1814-1913 (Barcelona, 1975).

North, D.C., Weingast, B.R., 'Constitutions and commitment: the evolution of institutions governing public choice in seventeenth-century England', Journal of Economic History, 49 (1989), pp. 803-32.

Okuno, Y., 'Entre la llana i el cotó. Una nota sobre l’extensió de la indústria del cotó als pobles de Catalunya al darrer quart del segle XVIIII', Recerques, 38 (1999), pp. 47-76.

Pamuk, S., 'Urban real wages around the Eastern Mediterranean in comparative perspective, 1100-2000', Research in Economic History, 23 (2006), pp. 209-28.

Pollard, S., The peaceful conquest. The industrialization of Europe, 1760-1970 (Oxford, 1981). 
Pomeranz, K., The great divergence: China, Europe, and the making of the modern world economy (Princeton, 2000).

Raveux, O., Sánchez, A., 'La adaptación tecnológica como factor de localización industrial. Una revisión de las investigaciones sobre la industria de hilados de algodón en Cataluña, 17721885, Investigaciones de Historia Económica, 17 (2010), pp. 65-94.

Sánchez, A., 'La era de la manufactura algodonera en Barcelona, 1736-1839', Estudios de Historia Social, 48-49 (1989), pp. 65-113.

Sánchez, A., 'Les activitats econòmiques a Barcelona, 1717-1833' in Sobrequés, ed., Història de Barcelona. El desplegament de la ciutat manufacturera, 5 (Barcelona, 1993).

Sánchez, A., ‘Crisis económica y respuesta empresarial. Los inicios del sistema fabril en la industria algodonera catalana, 1797-1839', Revista de Historia Económica, 18 (2000), pp. 485-523.

Sánchez, A., 'Les berguedanes i les primeres màquines de filar', in Maluquer de Motes, J., dir., Tècnics i tecnologia en el desenvolupament de la Catalunya contemporània, (Barcelona, 2000), pp. 161-75.

Sánchez, A., 'Els orígens de la industrialització, 1750-1832', in Nadal, J., Benaul, J.M., Sudrià, C., dirs., Atles de la industrialització de Catalunya, 1750-2010 (Barcelona, 2012), pp. 1-9.

Schneider, E.B., 'Real wages and the family: adjusting real wages to changing demography in pre-modern England', Explorations in Economic History, 50 (2013), pp. 99-115.

Solà, A., 'Indústria tèxtil, màquines i fàbriques a Berga', l'Erol, 47 (1995), pp. 12-5.

Solà, A., 'Filar amb 'bergadanes'. Mite i realitat d'una màquina de filar cotó', in La indústria tèxtil. Actes de les V Jornades d'Arqueologia Industrial de Catalunya (Barcelona, 2002), pp. $143-68$.

Solà, A., Aigua, indústria i fabricants a Manresa, 1759-1860 (Manresa, 2004). 
Thomson, J.K.J., A distinctive industrialization. Cotton in Barcelona, 1728-1832 (Cambridge, 1992).

Thomson, J.K.J., 'Transferring the spinning jenny to Barcelona: an apprenticeship in the technology of the Industrial Revolution', Textile History, 34 (2003), pp. 21-46.

Thomson, J.K.J., 'Transferencia tecnológica en la industria algodonera catalana: de las indianas a la selfactina', Revista de Historia Industrial, 24 (2003), pp. 13-50.

Thomson, J.K.J., 'Technological transfer to the Catalan cotton industry: from calico-printing to the self-acting mule', in Farnie, D., Jeremy, D., eds., The fibre that changed the world (Oxford, 2004), pp. 249-82.

Thomson, J.K.J., 'Explaining the 'take-off' of the Catalan cotton industry', Economic History Review, 58 (2005), pp. 701-35.

Torras, J., 'Estructura de la indústria pre-capitalista. La draperia', Recerques, 11 (1981), pp. 728.

Torras, J., 'Especialización agrícola e industria rural en Cataluña en el siglo XVIII', Revista de Historia Económica, 2 (1984), pp. 113-27.

Torras, J., 'L'economia catalana abans del 1800. Un esquema', in Nadal, J., ed., Història econòmica de la Catalunya contemporània, 1 (Barcelona, 1988), pp. 14-38.

Van Zanden, J.L., 'Wages and standards of living in Europe, 1500-1800', European Review of Economic History, 3 (1999), pp. 175-98.

Valls, F., La Catalunya atlàntica. Aiguardent $i$ teixits a l'arrencada industrial catalana (Vic, 2004).

Vilar, P., La Catalogne dans l'Espagne moderne. Recherches sur les fondements économiques des structures nationales (Paris, 1962). 
Vilar, P., 'La Catalunya industrial: reflexions sobre una arrencada i un destí', Recerques, 3 (1974), pp. 7-22.

Weber, M., The protestant ethic and the spirit of capitalism (English version, 1930). 